\title{
Irrigation Water Management of Horticultural Crops
}

\author{
Elias Fereres ${ }^{1}$ \\ IAS-CSIC and University of Cordoba, Cordoba, Spain \\ David A. Goldhamer \\ University of California, Kearney Agricultural Center, Parlier, CA 93648 \\ Larry R. Parsons \\ University of Florida, IFAS, Lake Alfred, FL 33850-2299
}

Because agriculture always has involved economic risks, mankind has long sought ways to minimize weather-related hazards that impact farming. Even in early civilizations, farmers noted that supplemental application of water to the land could minimize the effects of drought. The basic irrigation tenants have been understood at least since the time of the Sumerian civilization over 6000 years ago: one needed to get water on the land, hold it there as long as was needed, dispose of it when it was no longer required, and keep unwanted water away (Ryan and Pitman, 1998). It took many centuries of irrigation, however, for humankind to realize that irrigation can have negative environmental consequences, primarily from the accumulation of salt, and that irrigation practices must be managed for salt control (Gardner, 1993; van Schilfgaarde et al., 1974). Such negative impacts coupled with indirect adverse societal effects due to diversion of agricultural water, now present a threat to the future of irrigation that must be handled adequately if irrigated horticulture is to be a sustainable management system.

Irrigation uses $65 \%$ of all water diverted for various uses worldwide. The large amounts of water required for food production are primarily dictated by the linkage between biomass production and yield. Nevertheless, increased water demand for other uses in our society coupled with water scarcity is producing unprecedented pressure for reducing the share of freshwater used in irrigation. Until recently, society responded to increased demands for water by developing new supplies. That is no longer possible in many cases today as the economic and environmental costs of new water source developments exceed the perceived benefits. The alternative to new development is conservation of existing resources, for which a new conservation ethic is needed in all sectors of society. Agriculture, as the primary user of diverted water, is therefore under close scrutiny. High water demands and perceived wasteful practices make agriculture particularly vulnerable to criticism. Water for agricultural use is the first to be considered as a new source of supply for other uses, particularly in situations of scarcity. In fact, reallocation of water from agriculture to other sectors has already begun in many areas and is expected to increase in the future. At the same time that agriculture is being asked to give up water, the world's increasing population demands that agriculture increase food production. By 2020, the world will need $40 \%$ more grain (IFPRI, 1999) and also is shifting toward a greater consumption of fruits and vegetables. This conflict will be resolved in the coming years only if we can meet the challenge of increasing crop yield per unit water consumed, particularly in irrigated horticulture, a sector where water has been used lavishly until recently.

\section{WATER PRODUCTIVITY IN IRRIGATED HORTICULTURE}

Water used in irrigation is consumed via evaporation from crop or soil surfaces and may also be lost to runoff and deep percolation. In many instances, such water losses may be recovered within the basin and reused, albeit with some degradation in quality. Water conservation aimed at increased irrigation efficiency by changing the method of irrigation, for example, may not lead to net water savings if the losses conserved were recoverable (Seckler, 1996). Because of this uncertainty, water productivity (WP) is defined as the ratio of yield (measured as biological or economic output) to crop evapotranspiration (ET) (Seckler, 1996). Contrary to efficiency improvements, improving

${ }^{1}$ E.F. would like to thank F. Villalobos for his comments and A. Soriano for her skillfull technical assistance.
WPby increasing yield and/or reducing ET always results in net savings, thus reducing agricultural water requirements. This is a key point in assessing the opportunities for true water savings in horticultural crop cultivation and will be addressed in detail later in this paper.

Water productivity in irrigated agriculture varies widely and depends on many biophysical and management factors. Because variations in ET among crops are within an order of magnitude apart, by far the most important factor influencing WP is the economic value of the product. Horticultural products are usually high value and thus WP normally exceeds that of field and row (agronomic) crops. For example, using current values for yield and ET characteristic of California agriculture, the WP of corn is about $0.20 \$ / \mathrm{m}^{3}$, compared to $0.70 \$ / \mathrm{m}^{3}$ for almond, $5.00 \$ / \mathrm{m}^{3}$ for strawberry, and even more for greenhouse and ornamental crops. An extreme example of this occurs with vegetable crops grown under plastic in southeast Spain during the off-season. The combination of high market prices and low ET leads to a WP of about $10 \$ / \mathrm{m}^{3}$. While impressive, even this value cannot compete with that of industrial and urban uses. Nevertheless, it helps explain the trend of shifting irrigated acreage from low value field and row crops to horticultural crops in many water-scarce areas of the US, a trend that will probably increase worldwide (National Research Council, 1996). Indeed, the WP of an irrigation district in Southern Spain increased over a four year period as the proportion of horticultural crops increased (I. Lorite, L. Mateos, and E. Fereres, unpublished data).

This paper describes the evolution of water use as related to productivity with an emphasis on the U.S. experience, analyzes how irrigation systems and management have evolved since the early 1900s, and explores the challenges and opportunities for water conservation in horticulture. Because of the broad scope of the subject and limited space, the paper focuses primarily on tree crops although many principles are applicable to all horticultural crops.

\section{HISTORICAL PERSPECTIVES}

The history of irrigation parallels that of agriculture itself, as the early agricultural developments in the Fertile Crescent took place in an arid environment and, therefore, were inconceivable without irrigation. Janick (1979) reviewed graphically the history of irrigated horticulture until about the beginning of the 20th Century, when the ASHS was created. After 1900, irrigation development in the US accelerated as population growth triggered increased food production and this pattern was repeated on a worldwide basis for most of the 20th century (Howell, 2001). During the last two decades of the century, the irrigated area in the US remained relatively stable at about $20 \mathrm{M}$ ha although there were regional variations and some expansion in the mid-1990s (Howell, 2001). Currently, irrigated land represents $18 \%$ of all cropped lands but about $50 \%$ of all crop value (Howell, 2001). This high productivity of irrigated agriculture, coupled with shifting dietary patterns driven in part by the inclusion of fruits and vegetables as necessary components of a healthy diet, has led to the situation today where two thirds of the vegetables and three fourths of the fruit produced in the US are harvested from irrigated areas (Howell, 2001).

THE SEMI-ARID WESTERN U.S. Not surprisingly, irrigation development in the US began in the semi-arid southwest, where the very limited rainfall made irrigation essential for viable agricultural development. There is evidence of extensive irrigation works in the Salt River Valley of Arizona and other arid areas that were constructed by Native Americans, including the Hohokam and Pueblo tribes (Jensen, 1982). 
The Spanish brought irrigation to New Mexico in the 16th century and residents of their Missions in California also developed irrigated lands after the 17 th century. Modern irrigation development took place during the 19th Century and by 1870 , there were over 60,000 acres of irrigated horticultural crops in the plains around Los Angeles alone (Hundley, 1992). Irrigation expanded significantly in subsequent years and by the turn of the century, there were about 1.5 million acres of irrigated lands in California with nearly two-thirds devoted to horticultural crops (Hundley, 1992). This proportion would not be maintained in that state as time passed. Although California led the Western States in irrigation development in the early 1900s, the 1922 agreement on the use of Colorado River water accelerated the growth rate of irrigation throughout the west. Shortly thereafter, a number of institutional developments, including the formation of organized irrigation districts, helped promote the growth of irrigation, such that California's irrigated land expanded to 4.5 million acres by 1930 , about $50 \%$ of today's acreage (Hundley, 1992). Thereafter, the expansion of irrigation development slowed until the end of World War II. At that time, the irrigated area in the 17 western states totaled almost 20 million acres, which more than doubled in the next 30 years to 43 million acres (Jensen, 1982). Irrigation in the remainder of the US also expanded substantially after 1950, going from one to seven million acres in 1978 (Jensen, 1982).

Of the several initiatives launched for conducting research in horticultural irrigation in the west, the 1905 purchase by the State of California of a large land parcel near Davisville to be known as the University Farm would yield enormous returns over many decades ahead. A few years later, research on irrigation started on what soon became the Davis Campus of the University of California. The Department of Irrigation was established in 1936 with a faculty of 10 under the leadership of Frank Veihmeyer and initially focused on the irrigation of tree crops. This work continued for the next five decades. The findings of Veihmeyer and co-workers not only provided practical recommendations for efficient orchard irrigation for California's orchardists but also generated a new set of principles for quantitative irrigation management that subsequently guided irrigators around the world. Veihmeyer devised the water budget method of irrigation scheduling based on defining upper and lower limits of soil water storage that he considered readily available to plants. The water budget was then applied to minimize the number of irrigation applications (and associated labor costs) by allowing the crop to deplete most of the stored soil water between irrigations. Characteristic of his research program was his interest in carrying out long-term experiments (Veihmeyer, 1927, 1972). This unusual feature is highly exceptional in today's agricultural research. Reports of 20 to 25 years of research results were not uncommon then (Veihmeyer, 1972). An early Veihmeyer finding was that orchards were irrigated too early in the season in the Santa Clara Valley despite high water costs. He cited one case in the 1920s where water was purchased for 103 \$/acft; an inflation-adjusted price that would be unaffordable for any type of forming today. Additionally, Veihmeyer found that orchardists were applying water too early in spring, thus not making efficient use of winter rainfall (Veihmeyer, 1927).

Veihmeyer's findings were strongly influenced by the nature of the soils with which he worked - high soil water storage capacity and virtually unlimited depth. He noted and others have verified that tree crops can extract 300 to $400 \mathrm{~mm}$ of water from those types of soils without developing significant tree water stress (Fereres and Goldhamer, 1990; Veihmeyer, 1927, 1972). Veihmeyer used hand soil sampling to calculate consumptive use rates of orchard crops and, together with A.H. Hendrickson, a colleague from the Pomology Department at University of California, Davis, developed guidelines for irrigation management for most California tree crops (e.g., Hendrickson and Veihmeyer, 1951).

Veihmeyer in later studies demonstrated that it was possible to delay an irrigation until the major part of the root zone (usually above 1.8 $\mathrm{m}$ ) was depleted to the permanent wilting point without a yield loss. His previous work had shown that significant water extraction could occur to a soil depth of $3.6 \mathrm{~m}$ (Veihmeyer, 1927). In retrospect, that level of water supply must have been sufficient under the horticultural conditions that existed during those times, including widely spaced trees, to avoid negative impacts on yield with infrequent irrigations that resulted in very dry soil in the bulk of the root zone. Veihmeyer based his belief on the fact that more frequent irrigation failed to improve yields (Veihmeyer, 1972).

Following the pioneering work of Veihmeyer and Hendrickson, irrigation experiments conducted in less than ideal soils and/or with crops more sensitive than fruit trees to water deficits gave results less favorable to infrequent irrigation, challenging the views of these innovators. A controversy about the availability of soil water subsequently developed and lasted for decades (Uriu and Magness, 1967) until the dynamics of water in the soil-plant atmosphere system were understood more completely. The fact that Veihmeyer's views on soil water availability were eventually proven incorrect in many situations should not detract in the least from his contributions, both applied and theoretical, in the area of horticultural water management.

The HUMID SOUTHEAST. Several states in the humid southeastern US have rainfall greater than $1200 \mathrm{~mm} /$ year. Through the 1960s, while it was obvious that irrigation was essential for crop production in the arid western US, it was assumed that irrigation was not an economically viable practice in the humid southeast. After all, citrus and many other crops were grown successfully in Florida without irrigation. If annual rainfall matched or exceeded seasonal ET, why would irrigation be needed? In the 1950s, Savage (1953) reported that citrus irrigation was not economical in Florida. Later work by Koo (1963) and others showed that irrigation increased yield sufficiently to make it worth the investment. Why the change in opinion? The major reasons that irrigation can be advantageous in areas of the humid southeast include soil types, rainfall variability, and changes in irrigation technology. From the Carolinas through Georgia and Florida, the coastal plain has large areas of sandy soils with low water holding capacity. Water content at field capacity for some Florida citrus ridge soils can be as low as 6\%, and available water can be as low as $0.049 \mathrm{~cm}^{3} \cdot \mathrm{cm}^{-3}$. Such soils do not have the buffering capacity needed to cope with short dry spells and irrigation becomes necessary to improve yield. The large variability in annual rainfall in parts of the southeast is another factor. Koo (1963) noted that rainfall ranged from 836 to $1758 \mathrm{~mm}$ in two successive years. Recently, several El Niño events have caused record December rainfalls in Florida. This is normally a dry month. Periodic droughts have also occurred recently in the southeast. Along with reducing crop yield, these droughts have led to forest fires with consequent environmental damage. In addition to the annual variability, rainfall can be quite localized in space and time and does not necessarily come when needed. In some parts of the southeast, rainfall patterns produce very distinct dry and wet periods, as in Florida, where over $60 \%$ of the rain falls between June and September. Flowering and fruit set are critical periods for citrus and many other crops, and they occur during Florida's dry season. Inadequate rainfall or irrigation during these periods can significantly reduce yields.

When Savage (1953) concluded that irrigation was not economically viable, the predominant irrigation methods were flood (in coastal, flatwoods groves) and overhead sprinkler, portable perforated pipe, and volume gun. During dry periods, sprinklers were usually operated every 10 to 14 days, and growers often would delay the start of irrigation for several days, hoping that rain would eliminate that need. Hence, irrigation was not always applied on a timely basis. Water stress developed and fruit yield decreased. By increasing irrigation frequency, Koo (1963) showed that irrigation could be economical in citrus, even in years with above average rainfall. By keeping soil moisture above one-third depletion of available water from January through June and two-thirds depletion for the rest of the year, he increased yields over nonirrigated controls. This does not imply that Savage (1953) was incorrect in his analysis. At that time, growers did not know how to manage their high-volume systems or could not afford the labor costs of frequent irrigation needed to improve yield. It was only after permanent systems, particularly microirrigation, became available that it was possible to expand the area devoted to irrigated horticulture in the southeast. For example, microsprinkler irrigation was introduced into Florida from South Africa in the early 1970s. When these systems were shown to provide some frost protection for citrus (Parsons et al., 1982), microsprinklers were installed on thousands of hectares of Florida citrus. Florida became one of the most rapidly expanding microirrigation markets in the United States during the 1980s when a series of five devastating freezes hit the state. Now the majority of Florida citrus acreage is irrigated with 
microsprinklers because of the dual advantage of high-frequency irrigation plus frost protection. Smajstrla et al. (1995) estimated that in 1994, about $20 \%$ of the total U.S. microirrigated area was in Florida fruit crops (primarily citrus).

\section{PROCESSES IN IRRIGATION MANAGEMENT OF HORTICULTURAL CROPS}

Three questions must be answered by those who irrigate: 1) how much water to apply, 2) when to apply it, and 3) how to apply it. Good management uses quantitative approaches to provide answers to these questions and over the years, a myriad of methods and techniques have been developed for this purpose. This is also an indication that irrigation management is a complex subject, not always well understood by farmers and the public alike, and subject to variable, site-specific conditions.

CONSUMPTIVE USE REQUIREMENTS. Theoretical and empirical research on evaporation from cropped surfaces has generated many approaches to compute ET, which is the basic input for determining how much water to apply. Standard procedures for calculating ET were developed successfully by Dorenboos and Pruitt (1974) but recently have been modified by Allen et al. (1998) and by the ASCE (Walter et al., 2000). All methods are based on calculating a reference ET that is multiplied by an empirically determined crop coefficient $(\mathrm{Kc})$ that incorporates specific features of each crop. At present, there are good estimates of $\mathrm{Kc}$ values for most horticultural crops, even though most of the Kc research has been conducted on the major field crops (Allen et al., 1998). One exception is the lack of sufficient information on orchard water requirements for young trees. A relationship between ET and ground shaded area, developed for young almond trees (Fereres and Goldhamer, 1990) has been used successfully for other deciduous and evergreen fruit trees to adjust mature orchard ET to that of a developing tree canopy. Despite their empiricism, the accuracy of ET estimates is sufficient for most management applications, although there are more mechanistic models based on the theory of evaporation (Monteith, 1965) that will be applied in the future as information on their parameterization becomes available.

Water deficits can reduce crop transpiration (T) either by affecting vegetative growth, thus reducing canopy size, or by closing stomata, thus reducing canopy conductance. Because of the linearity between radiation interception and biomass production, reducing $\mathrm{T}$ by developing smaller canopies normally decreases WP and should be avoided in intensive horticulture (Hsiao, 2000). The other option, regulation of canopy $\mathrm{T}$ via stomata closure, presents some interesting and exploitable differences among horticultural crops (see section Towards Reducing Irrigation Needs in Horticulture). It is well known that $\mathrm{T}$ is controlled by stomata, but a distinction must be made between the impact of stomatal behavior on $\mathrm{T}$ at the leaf or individual plant levels versus at the crop canopy level. Transpiration from canopies is regulated by the aerodynamic and canopy conductances, and the extent to which $\mathrm{T}$ is influenced by changes in stomatal conductance depends on the relative magnitude of the two. Tall, rough canopies such as those of orchards, have aerodynamic conductances that are much greater than those of the short, smooth canopies of field and vegetable crops. Tree canopies are considered to be well coupled to the atmosphere and exchange $\mathrm{CO}_{2}$ and $\mathrm{H}_{2} \mathrm{O}$ effectively with its environment, while short canopies, particularly under low wind, are poorly coupled and offer much more resistance to mass transfer (Jarvis and McNaughton, 1986). Under poor coupling (smooth crop and/or low wind speed), stomatal closure increases crop temperature, which in turn, increases the vapor pressure gradient between the leaf and the atmosphere, increasing $\mathrm{T}$. In this case, stomatal control is not effective in controlling $\mathrm{T}$ and large reductions in its magnitude (that also affects photosynthesis substantially) are needed to decrease canopy T. To the contrary, in well-coupled orchards, effective heat transfer from leaves prevents a large difference between canopy and air temperature and there is nearly a linear relation between transpiration and canopy conductance. For instance, working with olive trees with a 3-m height and around 50\% groundcover, Villalobos et al. (2000) found a relative sensitivity of $\mathrm{T}$ to changes in canopy conductance of about 0.9 during most of the daytime. Thus, a given reduction in stomatal conductance will reduce olive $\mathrm{T}$ by almost the same magnitude. By contrast, similar measurements over garlic at full cover showed a sensitivity of $\mathrm{T}$ to reduction in stomatal conductance below 0.3 , meaning that the relative decrease in $\mathrm{T}$ will be less than $30 \%$ the reduction in conductance (F.J. Villalobos, L. Testi, R. Rizalli, and F. Orgaz, unpublished data). Thus, it's clear that stomatal closure will have a variable impact on $\mathrm{T}$ depending on features of the crop canopy and its environment. The extensive body of research on stomatal responses to water stress carried out at the leaf and individual plant levels has largely ignored this fact. This example highlights the risks of investing in crop molecular biology research without devoting enough attention to the relevant mechanisms that govern crop behavior in the field.

IRRIGATION METHODS. Surface irrigation is the most common method of applying water to the land. There are a number of surface irrigation techniques used in horticulture but they all have a fundamental limitation; the depth of water applied is determined by the infiltration rate of the soil. With surface irrigation, better engineering designs, management, and land preparation (e.g., laser leveling), new techniques are now used to control the application depth and to distribute the water as uniformly as possible across the field. However, it's not possible to overcome the inherent variability in soil water intake rates and, therefore, the variability in infiltrated water within a field. Surface irrigation can be efficient in uniform soils of moderate to low infiltration rate but inefficient in heterogeneous and/or light-textured soils. The invention of impact sprinkler irrigation in the 1940s took the control of the distribution of infiltrated water away from the soil and gave it to the manager. It was then possible to apply any required depth to areas where land leveling was not feasible and, although the initial sprinkler systems had even more labor requirements than surface systems, present mechanized and solid set systems require little labor. The uniform distribution of sprinkler-applied water is affected by wind which also leads to increased spray evaporation and drift losses in arid climates. Moreover, sprinkler irrigation can be problematic in orchards due to canopy interception of the spray patterns resulting in poor distribution uniformity.

Both horticulturists and the general public associate drip or trickle irrigation with efficient water application. Drip irrigation consists of a permanent system of plastic pipes that uses emitters to localize the water placement near individual plants using high frequency application and low discharge rates. Drip irrigation development started after World War II and was in use in greenhouses in the U.S. in the 1950s. When S. Blass developed the first commercial drip system for agricultural crops in Kibbutz Hatzerim, Israel, in the early 1960s, little did he know that he was going to change the landscape of irrigated horticulture in more than one sense. Engineering developments preceded scientific advancement in drip irrigation as the first research reports on this method appeared several years after it was commercially available (e.g., Goldberg et al., 1971). Subsequent research showed that in addition to improved uniformity of water distribution, drip irrigation could increase fertilizer use efficiency by using direct injection, allow better field access for equipment, reduce humidity-associated fungal diseases, and decrease the extensiveness of weeds. On the other hand, weed control in the frequently wetted zones proved difficult due to the accelerated breakdown of herbicides (Fereres and Goldhamer,1990). Microsprinklers, an off-shoot of drip technology wet a larger surface area with various pattern shapes, and operate on a frequency between drip and conventional impact sprinklers. In addition to providing some frost protection, their advantages over drip include fewer emission devices required per field, the development of larger plant root volumes which would presumably enhance tree anchorage and the mining of soil nutrients, and better soil aeration and weed control in the wetted zones. It is also easier to detect if microsprinklers are clogged.

Operational and management advantages of sprinklers and microirrigation (drip and microsprinkler) systems have led to a large shift in the US from surface irrigation to these pressurized methods. Howell (2001) reported that between 1979 and 1994, the surface irrigated area in the U.S. declined from two-thirds to one-half of the total irrigated land and particularly noted that the use of microirrigation grew very rapidly during this period with an annual growth rate of over $400 \%$. This amounted to one million ha in 2000 or $5 \%$ of the total irrigated area. Within the US, California has the greatest area in microirrigation 
but several other states, including Florida, Georgia, Hawaii, Michigan, and Texas, have substantial acreage located in humid areas. Irrigation hardware that now exists is more than sufficient to offer horticulture a vast range of options for efficient and uniform water application, so much so that economic and social considerations mostly determine the final choice of method and equipment.

IRRIGATION SCHEDULING. With surface and portable sprinkler irrigation techniques, each irrigation required,labor to be mobilized and thus, a primary management objective was to irrigate as infrequently, as possible. Other sprinkler and microirrigation methods make the frequency issue irrelevant and the primary concern is to match applications to crop requirements. While most irrigators take intuitive or qualitative approaches to scheduling, this subject has been extensively researched in horticulture and many quantitative procedures have been proposed based on the water budget, soil, and plant indicators. The water budget method is probably the most widely used scheduling technique. With surface irrigation, the approach is to compute the available soil water storage and a threshold for allowable depletion. Then, rainfall and irrigation inputs adjusted for application efficiency are balanced against crop ET, runoff, and percolation outputs. The increased availability of local and regional ET data, and the expansion of microirrigation, where water budget information is most easily implemented, has encouraged growers to adopt the water budget technique. Additionally, computer models pioneered by Marvin Jensen (Jensen et al., 1970), who has promoted scientific irrigation scheduling in the U.S. for the last 3 decades, also have contributed to the success of this technique.

Monitoring soil moisture is another scheduling procedure that has been used in horticulture since the first grower scrutinized a hand full of semi-moist soil. The first instrument used to quantify soil water status was the tensiometer, developed by L.A. Richards (Richards and Neal, 1936). Historically, the chief limitation of tensiometers was their relatively narrow working range of soil water potential, which made their use with surface irrigation methods problematic due to the wide range of soil water contents between irrigation. Thus, they were best used in managing irrigation in shallow and/or sandy soils. The expansion of microinigation, where soil moisture is maintained at relatively high levels well within the range of tensiometers has helped these tried and true instruments make, something of a comeback in irrigation management. Rather than assess soil water potential, neutron probes measured moisture content and thus could be used to assess amounts of water required to refill soil profiles. However, the continued decline of surface irrigation, where this information is most applicable, and increased regulatory requirements for radioactive materials, currently dampens enthusiasm for this monitoring technique.

The last decade has seen renewed efforts in developing a new generation of soil moisture sensors based on certain electrical properties, such as resistance, capacitance, and time domain reflectometry. New features include continuous monitoring and trend evaluation with appropriate software. All of these new sensors require very careful installation due to their very small measurement domain. One important limitation of soil moisture monitoring is the difficulty in coping with the spatial variability of soil water properties and of irrigation water distribution. Another is being able to successfully relate the soil-based data to plant performance.

Even though optimizing the plant biomass or fruit production is the goal of irrigation, the plant is rarely the primary focus in irrigation scheduling techniques. Although a variety of methods exist to evaluate plant water status directly or indirectly, there are few proposals to use such measurements for irrigation scheduling in horticulture (Goldhamer and Fereres, 2001; Peretz et al., 1984; Shackel et al., 1997). Canopy temperature as measured by infrared thermometry (Jackson et al., 1977), an indirect measurement technique used in agronomic crops, failed with tree crops most likely due to the previously mentioned coupling between tree canopies and the atmosphere that minimizes leaf temperature increases with water stress. Using directly measured plant water status in irrigation management is hampered by the difficulty of relating the measurements to timing and amount of irrigation. At present, improved knowledge of plant responses to water combined with recent advances in monitoring equipment and sensors is generating renewed interest in this scheduling approach for fruit tree irrigation.

The established parameter for quantifying plant water status is water potential ( $\psi ;$ Hsiao, 1990). Shackel et al. (1997) proposed using stem $\psi$, which is measured on a covered leaf, making it less coupled to the aerial environment and less variable than leaf $\psi$ measurements that are influenced by stomatal behavior and leaf shade history. Naor (2000) found that stem $\psi$ was a better indicator of water stress than predawn or midday leaf $\psi$. Another water status indicator is based on daily stem diameter fluctuations that are directly related to changes in plant water status (Klepper et al., 1971). Recent advances in sensor technology allow for the continuous monitoring of stem or fruit diameter (Huguet et al., 1992). Commercial adoption of these indicators for scheduling requires knowledge of how the measurements impact crop yield, an issue complicated by the fact that species and processes differ in their sensitivity to water stress. Nevertheless, there are some promising commercial plant-based scheduling approaches for fruit tree irrigation, such as that proposed by Lampinen et al. (2001) for using stem $\psi$ in prunes. These protocols, which are normalized for evaporative demand, already have been adopted by a number of prune growers in California. Drawbacks of the method are that it is difficult to conduct frequent manual stem $\psi$ monitoring and that the measurement cannot currently be automated. At the time, the only currently available plantbased water status monitoring device that can continuously record data and potentially be incorporated into a system controller for automated irrigation is the trunk diameter sensor. Ebel et al. (1995) proposed the use of fruit growth for irrigation scheduling in apple and Goldhamer and Fereres (2001) presented protocols based on trunk diameter measurements to schedule orchard irrigations.

\section{TOWARDS REDUCING IRRIGATION NEEDS IN HORTICULTURE}

As populations grow, there is little doubt that in the near future some water currently used by agriculture will be diverted to competing sectors of society. This begs an answer to the question of what opportunities exist for agricultural water conservation. For horticultural crops in intensively irrigated areas such as California and Florida where use of drip and microsprinkler irrigation is now widespread, application efficiencies in well designed, maintained, and managed systems are already high. The two components required in the water budget approach for irrigation scheduling - Kc and ET - have been established with decades of research. Opportunities for improving their accuracy are limited but the effectiveness of this and soil-based methods of irrigation scheduling can be improved with additional grower education efforts.

REDUCING SURFACE EVAPORATION. One obvious approach to reducing ET is to reduce or eliminate E since it has no direct impact on crop production as does $\mathrm{T}$. There is a perception that microirrigation reduces E significantly over that of other irrigation methods. In vegetable crops, the potential E savings by shifting to drip are probably negligible, as evaluated in a lysimeter study, where the ET of drip and furrow-irrigated tomatoes was equal (Pruitt et al., 1984). In tree crops, however, E savings in the first years of the orchard are substantial when a surface system is changed to microirrigation (Fereres et al., 1982). Within the last two decades, drip emitters have been developed that combat root intrusion, the single most troublesome factor in the development of subsurface drip irrigation systems. The seasonal savings possible in permanent crops by eliminating $\mathrm{E}$ depend on plant size and conventional surface system placement. The $\mathrm{E}$ losses from mature and young drip-irrigated olive orchards were evaluated by Bonachela et al. (2001) who found that E represented about $8 \%$ of an orchard with a $36 \%$ canopy cover, or $38 \mathrm{~mm}$ of evaporation. Therefore, the savings by going from surface to subsurface drip in mature orchards must be small. The overall conclusion is that the potential reduction in $\mathrm{E}$ by changing the irrigation method to microirrigation or to subsurface from surface drip is important only for permanent crops in their first few years. For the other sectors of irrigated horticulture, such E reduction will have little impact on the ET demand.

DEFICIT IRRIGATION AND STRESS MANAGEMENT. Short of reducing farmed acreage or shifting to lower water use winter crops from summer crops, the most direct way to reduce the water demands of efficient, modern-day agricultural operations is to reduce the actual consumptive use of the plants. Deficit irrigation is the application of water below the ET rate and can be performed in several fashions. Progressive or 
sustained deficit irrigation is the systematic application of water at a constant fraction of potential ET throughout the season. Regulated deficit irrigation (RDI) is performed by imposing water deficits only at certain crop developmental stages (Chalmers et al., 1981). It should be understood that, depending on the stored soil water levels and on the rainfall patterns and amounts, deficit irrigation may or may not reduce ET below its maximum potential.

We believe that the potential for water savings of deficit irrigation in orchard crops has been relatively unexplored so far. This is due to the aforementioned fact that deficit irrigation in most field and row crops - the oldest and most researched crop plants - normally reduces yield and therefore, profit in direct proportion to the magnitude of the ET deficit. The prospects for reducing ET in many vegetable crops are also limited because most of the relationships between yield and ET are linear. However, the nature of tree crop production, where fruit rather than biomass is the marketable product and fruit quality (appearance, size, taste, etc.) is important, offers the potential to use deficit irrigation to reduce water use while maintaining or even improving grower profit without changes in cropping acreage and/or cropping patterns. Moreover, the higher WP of horticultural crops likely will attract water currently used in low-value field crops, increasing the acreage where deficit irrigation can be effectively used to save water by reducing $\mathrm{T}$.

The goal of the initial RDI work in the 1970s in Australia and New Zealand was to reduce vegetative growth and thus, summer pruning, in excessively vigorous, late maturing peach trees. Associated water savings were of secondary importance. The researchers were successful in maintaining or even increasing yield (larger fruit size) when they stressed the trees only at stages of slow fruit growth and saved about $25 \%$ of potentialET(Mitchell et al., 1989). Researchers in Spain and California tried to reproduce these results under different conditions and failed (Girona et al., 1993, 2002; Goldhamer et al., 2002). This illustrates the specificity of RDI results and how transferability requires making adjustments to variety, soil type and evaporative demand.

One common feature of many deficit irrigation regimes is the improvement in fruit quality, as reported long ago by Uriu and Magness (1967). Proebsting carried out many experiments that clearly demonstrated that mild water deficits enhanced the quality of apples (Proebsting et al., 1984). It is unfortunate that such quality improvements are not always recognized by markets, although the situation may be changing. Fruit production has normally two yield components--fruit size and load. Often, there is a direct relationship between fruit production and ET for fruit trees, similar to those found with field crops. Working with mature navel orange trees, Goldhamer and Salinas (2000) found that fruit yield and applied water correlated linearly but with a slope above the 1:1 relationship (Fig. 1a). On the other hand, the relationship between gross revenue (\$US/ha) and water applied was completely different (Fig. 1b). Many of the RDI regimes, especially those that imposed water stress early in the season, had higher gross revenue than the control while applying 100 to $200 \mathrm{~mm}$ less water. This was due to significantly lower peel creasing, a disorder that reduces fruit value.

Other than fruit appearance, horticultural crops often possess other unique yield components that can be exploited to reduce $\mathrm{T}$ without reducing grower profit. An example is fruit hydration in prune orchards. Goldhamer et al. (1994) and Lampinen et al. (2001) showed that in the 6 to 8 weeks before harvest, water stress can reduce fruit hydration without affecting dry fruit weight or subsequent fruit load. Additionally, energy and 200 to $250 \mathrm{~mm}$ of water are saved, since prunes must be dried in ovens. Another example where unique fruit development patterns can be exploited with RDI is in pistachio nuts. Rapid kernel hull and shell growth occurs in the first 3 to 4 weeks of the season but rapid kernel growth does not begin until about week 10. Thus, RDI (100 to $200 \mathrm{~mm}$ of water less than potential ET) can be imposed between these two periods without negative impacts on production (Goldhamer and Beede, 1992). In olive, Moriana et al. (2003) showed that the relation between ET and yield is curvilinear. That meant that WP is not constant, varying from $9 \mathrm{~kg} \cdot \mathrm{ha}^{-1} \cdot \mathrm{mm}^{-1}$ at maximum ET up to $22 \mathrm{~kg} \cdot \mathrm{ha}^{-1} \cdot \mathrm{mm}^{-1}$ when ET was about $60 \%$ of maximum. Thus, optimum olive ET is determined by water costs and olive prices and will normally be less than maximum ET. Deficit irrigation after harvest may be another way of conserving water in some species. Larson et al. (1988) demonstrated with early harvest peach trees that reducing the number of postharvest surface irrigations by more than half did not negatively affect subsequent orchard production.

As the knowledge base of exploiting water stress in horticultural crops for beneficial uses is quite limited, a distinction often must be made between current and potential positive effects of RDI. An example of this can be found in almond trees. Goldhamer and Viveros (2000) showed that mild stress imposed with a sustained deficit irrigation (SDI) regime (applied water at $85 \%$ of ET) hardly affected production. However, a potentially more significant finding involved RDI regimes that imposed moderate to severe preharvest (April-July) stress. These strategies reduced canopy size and individual kernel weight but had no influence on fruit load. In other words, the smaller, more compact RDI trees had higher fruiting density than fully irrigated trees. Thus, an increase in planting density under RDI could increase yields compared with fully irrigated orchards at a standard density. Moreover, this type of RDI would address two critical health issues facing the industry-agricultural burning and dust during harvest. The former would be reduced or eliminated due to much lower vegetative growth and pruning residues. The latter would be eliminated since earlier hull splitting (Goldhamer and Fereres, unpublished data) would allow nuts to dry on the trees and be harvested directly into bins or carriers, rather

Fig. 1. Relationships between (a) gross yield, and (b) gross revenue for numerous regulated deficit irrigation (RDI) regimes in mature navel orange (frost nucellar) trees grown under high evaporative demand. Adapted from Goldhamer and Salinas, 2000.
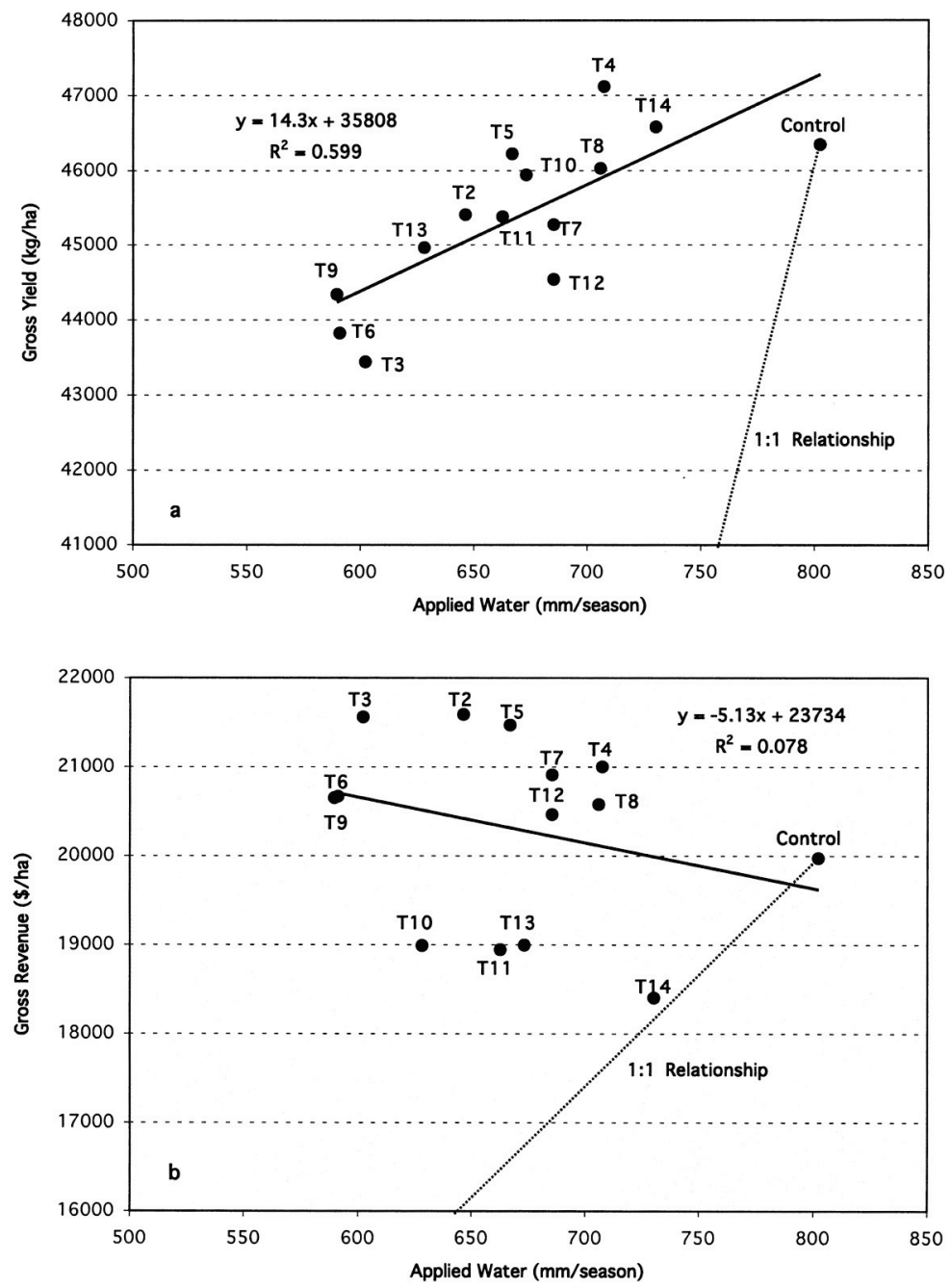

HortScience, Vol. 38(5), August 2003 
than drying and being harvested on the ground, which is the current practice that produces dust during the sweeping and nut retrieval operations. Ant damage and soil-borne bacteria infection would also be eliminated by using this RDI-driven technique.

Wine grape is another crop where stress management has improved fruit quality. Indeed, it was illegal to irrigate wine grapes until recently in some countries, such as Spain, simply because of the perceived negative impact on wine quality. Water deficits reduce berry size at harvest and thus increase the ratio of skin to pulp, leading to more favorable color and flavor. The yield reduction produced by RDI is reflected in smaller and fewer berries per cluster and fewer clusters per vine. However, enologists usually contend that this is more than offset by the improved wine quality. Recently, the beneficial aspects of partial root zone drying (PRD) - a technique where the deficits are applied by alternating irrigation on each side of the tree or vine about every 2 weeks - on wine grape production have garnered considerable interest as a technique that applies RDI to improve wine quality while reducing T ( Stoll et al., 2000). The hypothesis behind this approach is that hormonal signals from the dry part of the roots alter partitioning and reduce vegetative growth allowing for better light penetration that improves fruit quality. It is unknown if the same effects could be obtained with another RDI regime that would apply the same amount of water without placing it on alternate sides, since there are no published results that have reported on such a comparison in wine grapes. Nevertheless, work by Goldhamer et al. (2002) on peach and by Caspari et al. (2002) on apple comparing RDI regimes applied conventionally and via PRD reported no differences in yield and quality parameters between placement methods and therefore do not support the positive claims of PRD proponents for those two species.

In the future, the reduction of crop water requirements in horticulture must be based on a systematic assessment of the benefits of stress management. There is an urgent need to invest in research needed to document the benefits of stress in terms of 1) improved fruit quality, 2) reduced consumptive use or irrigation requirements, and 3 ) improved grower profits. Without demonstrated benefits, stress management strategies will not be adopted by most growers.

INCREASING SUPPLIES: THE USE OF RECLAIMED WATER. An indirect benefit of deficit irrigation is the more efficient use of rainfall, as the partial soil water depletion allows for capturing rain within the crop root zone, thus reducing drainage losses. The current advances in weather forecasting can assist in the development of flexible deficit irrigation strategies that would leave some storage capacity for the anticipated rainfall. Future irrigation schedules should be designed to make the most efficient use of seasonal rainfall as a means of increasing available supply. An alternative source of supply is reclaimed water. Reclaimed water is treated wastewater that is recycled and used again. In the past, urban wastewater disposal commonly had been handled by treating the wastewater and then disposing of it in the most convenient manner. Usually, this meant discharging the water into a nearby river or lake, spraying it onto a field, or loading it into a percolation pond. Disposal was the primary consideration since the amount of wastewater continued to increase as an unavoidable consequence of population growth. As wastewater volume increased, concerns were raised about the effects on discharge sites. This led to consideration of alternate uses such as irrigation. While the idea of converting wastewater to reclaimed water for irrigation was not a new one, using reclaimed water for irrigation was a relatively small-scale activity in many parts of the U.S. before 1980 .

Florida citrus growers initially rejected the use of reclaimed water because of concerns about possible heavy metal contamination, potential pathogen problems, flooding, and lack of flexibility in water application during periods of high rainfall. Growers also raised concerns over public perceptions and feared that there might be a degradation of fruit quality from trees irrigated with reclaimed water. The fears proved to be unfounded, and citrus did very well even at excessively high (2500 $\mathrm{mm} /$ year) irrigation rates with reclaimed water (Parsons et al., 2001). Reclaimed water is now used on about 80,000 ha of public access areas, golf courses, and agricultural crops in Florida (Florida DEP, 2002). Several severe droughts increased interest in use of reclaimed water, and Florida now leads the nation in total reuse flow, followed by California, Texas, and Arizona, all four states representing more than $90 \%$ of the water reuse in the U.S. Reclaimed water has become a reliable water source for irrigation and its use will continue to increase in the future.

\section{CONCLUSIONS}

Improvements in irrigation system application uniformity, and scheduling management have occurred steadily over the past century, resulting in higher water productivity, especially for horticultural crops. Decreasing water availability, higher costs, and heightened environmental concerns of agricultural water diversions are issues that growers will not be able to ignore in the future. Solutions will not be easy and likely will be multifaceted. Certainly, waste water reuse on selected agricultural crops will expand. However, we believe that opportunities to improve application efficiency and develop new agricultural water supplies increasingly will be limited in the future. Greater prospects exist for the development of more precise irrigation scheduling approaches that use soil and more explicitly, crop water status as triggers for irrigation water application. This will require better water status monitoring techniques, including robust and affordable sensors that can be linked to automated system controllers. In the future, regulated deficit irrigation use should become more prevalent, especially in high water cost areas and with high value crops. Adoption of RDI will be driven by grower awareness that they can save significant amounts of water while managing water stress to improve certain yield components in a number of important tree crops and vines. On a wider scale, improved availability of increasingly more accurate ET information will encourage adoption of scientific irrigation scheduling where plant stress is not desirable. As research continues to supply new information and technologies, the often adversarial relationships between urban, agricultural, and environmental interests in the water resources area, likely will be replaced by a more cooperative atmosphere created around firm scientific facts.

\section{Literature Cited}

Allen, R.G., L.S. Pereira, D. Raes, and M. Smith. 1998. Crop evapotranspiration: Guidelines for computing crop water requirements. FAO Irrigation and Drainage paper no. 56. FAO, Rome, Italy.

Bonachela, S., F. Orgaz, F.J. Villalobos, and E. Fereres. 2001. Soil evaporation from drip-irrigated olive orchards. Irr. Sci. 20:65-71.

Caspari, H.W., T. Einhorn, S.Neal, P. Aspach, and B.G. Leib. 2002. Irrigation volume (?) rather than placement determines response of apple to deficit irrigation. XXVI Intl. Hort. Congr., Toronto, Canada. p. 346.

Chalmers, D.J., P.D. Mitchell, and L.Van Heek. 1981. Control of peach tree growth and productivity by regulated water supply, tree density and summer pruning. J. Amer. Soc. Hort. Sci. 106:307-312.

Doorenbos, J. and W.O. Pruitt. 1974. Crop water requirements. FAO Irr. Drain. paper 24. FAO, Rome, Italy.

Ebel R.C., E.L. Proebsting, and R.G. Evans. 1995. Deficit irrigation to control vegetative growth in apple and monitoring fruit growth to schedule irrigation. HortScience 30:1229-1232.

Fereres, E. and D.A. Goldhamer. 1990. Irrigation of deciduous fruit and nut trees, p. 987-1017. In: B.A. Stewart and D.R. Nielsen (eds.). ASA Monogr. 30 - Irrigation of agricultural crops.

Fereres, E., D.A. Martinich, T.M. Aldrich, J.R. Castel, E. Holzapfel, and H. Schulbach. 1982. Water requirements of young almond trees under drip irrigation in the Central Valley. Calif. Agr. 36:11-12.

Florida Department of Environmental Protection. 2001 Reuse inventory 2002. Tallahassee, Fla.

Gardner, W.R. 1993. The future of irrigated areas, p. 97-99. In: D.R. Buxton, R. Shibles, R.A. Forsberg, B.L. Blad, K.H. Asay, G.M. Paulsen, and R.F. Wilson (eds.). Intternational crop science. vol. 1. Crop Sci. Soc. Amer., Inc., Madison, Wis.

Girona, J., M. Mata, D.A. Goldhamer, R.S. Johnson, and T.M. DeJong. 1993. Patterns of soil and tree water status and leaf functioning during regulated deficit irrigation scheduling in peach. J. Amer. Soc. Hort. Sci. 118(5): 580-586.

Girona, J., M. Mata, E. Fereres, D.A. Goldhamer, and M. Cohen. 2002. Evapotranspiration and soil water dynamics of peach trees under water deficits. Agr. Water Mgt. 54(2):107-122.

Goldberg, D., B. Gornat, and B. Bar-Yosef. 1971. Distribution of roots, water and minerals as a result of trickle irrigation. J. Amer. Soc. Hort. Sci. 96: 645-648.

Goldhamer, D.A. and M. Salinas. 2000. Evaluation of regulated deficit irrigation on mature orange trees grown under high evaporative demand. Proc. Intl. 
Soc. Citricult. IX Congr. 227-231.

Goldhamer, D.A., M. Salinas, C. Crisosto, K.R. Day, M. Soler, and A. Moriana. 2002. Effects of regulated deficit irrigation and partial root zone drying on late harvest peach tree performance. Acta Hort. 592(1):343-350.

Goldhamer, D.A. and E. Fereres. 2001. Irrigation scheduling protocols using continuously recorded trunk diameter measurements. Irr. Sci. 20:115-125.

Goldhamer, D.A., G.S. Sibbett, R.C. Phene, and D.G. Katayama. 1994. Early irrigation cutoff has little effect on French prune production. Calif. Agr. 48(4):13-17.

Goldhamer, D.A. and M. Viveros. 2000. Effects of preharvest irrigation cutoff durations and postharvest water deprivation on almond tree performance. Irr. Sci. 19:125-131.

Goldhamer, D.A. and R. Beede. 1992. Results of four years of regulated deficit irrigation on deep rooted pistachio trees. California Pistachio Industry 1992-93 Annu. Rpt. Calif. Pistachio Comm., Fresno.

Hendrickson, A.H. and F.J.Veihmeyer. 1951. Apricot irrigation. Calif. Agr. $5: 5-13$.

Howell, T.A. 2001. Enhancing water use efficiency in irrigated agriculture. Agron. J. 93:281-289.

Hsiao, T.C. 1990. Measurements of Plant water status, p. 243-279. In: B.A. Stewart and D.R. Nielsen (eds.). ASA Monogr. 30.

Hsiao, T.C. 2000. Leaf and root growth in relation to water status. HortScience 35:1051-1058.

Huguet, J.G., S.H. Li, J.Y. Lorendeau, and G. Pelloux. 1992. Specific micromorphometric reactions of fruit trees to water stress and irrigation scheduling automation. J. Hort. Sci. 67:631-640.

Hundley, N. 1992. The great thirst. Californians and water, 1770s-1990s. Univ. Calif. Press, Berkeley.

IFPRI. 1999. World Food Prospects: Critical issues for the early twenty first century. Intl. Food Policy Res. Inst., Wash., D.C.

Jackson, R.D., R.J. Reginato, and S.B. Idso. 1977. Wheat canopy temperature: a practical tool for evaluating crop water requirements. Water Resour. Res. 13:651-656.

Janick, J. 1979. Horticulture's ancient roots. HortScience 14:299-313.

Jarvis, P.G. and K.G. McNaughton. 1986. Stomatal control of transpiration. Adv. Ecol. Res. 15:1-49.

Jensen, M.E., D.C.N. Robb, and C.E. Franzoy. 1970. Scheduling irrigations using climate-crop-soil data. J. Irr. Drain. Div. Amer. Soc. Civ. Eng. 96: 25-38.

Jensen M. E. 1982. Overview - Irrigation in the U.S. arid and semiarid lands. Paper prepared for the OTA, U.S. Senate, Wash., D.C.

Klepper, B.,V.D. Browning, and H.M. Taylor. 1971. Stem diameter in relation to plant water status. Plant Physiol. 48:683-685.

Koo, R.C.J. 1963. Effect of frequency of irrigations on yield of orange and grapefruit. Proc. Florida State Hort. Soc. 76:1-5.

Lampinen, B.D., K.A. Shackel, S.M. Southwick, and W.H. Olson. 2001. Deficit irrigation strategies using midday stem water potential in prune. Irr. Sci. 20:47-54.

Larson, K.D., T.M. DeJong, and R.S. Johnson.1988. Physiological and growth responses of mature peach trees to postharvest water stress. J. Amer. Soc. Hort. Sci. 113:296-300.

Mitchell, P.D., P.H. van den Ende, and D.J. Chalmers. 1989. Responses of 'Bartlett' pear to withholding irrigation, regulated deficit irrigation and tree spacing. J. Amer. Soc. Hort. Sci. 114:15-19.

Monteith, J.L. 1965. Evaporation and environment. Symp. Soc. Expt. Biol. XIX:205-234.

Moriana, A., F. Orgaz, M. Pastor, and E. Fereres. 2003. Yield responses of a mature olive orchard to water deficits. J. Amer. Soc. Hort. Sci. (in press).
Naor, A. 2000. Midday stem water potential as a plant water stress indicator for irrigation scheduling in fruit trees. Acta Hort. 537:447-454.

National Research Council. 1996. A new era for irrigation. Natl. Acad. Press, Wash., D.C.

Parsons, L.R., T.A. Wheaton, and W.S. Castle. 2001. High application rates of reclaimed water benefit citrus tree growth and fruit production. HortScience 36(7): 1273-1277.

Parsons, L.R., T.A. Wheaton, D.P.H. Tucker, and J.D. Whitney. 1982. Low volume microsprinkler irrigation for citrus cold protection. Proc. Fla. State Hort. Soc. 95:20-23.

Peretz, J., R.G. Evans, and E.L. Proebsting. 1984. Leaf water potentials for management of high frequency irrigation on apples. Trans. ASAE 27: 437-442.

Phene, C.J., R.B. Hutmacher, K.R. Davis, and R.L. McCormick. 1990. Waterfertilizer management of processing tomatoes. Acta Hort. 277:137-143.

Proebsting, E.L, S.R. Drake, and R.G. Evans. 1984. Irrigation management, fruit quality and storage life of apples. J. Amer. Soc. Hort. Sci. 109:229-232.

Pruitt, W.E., E. Fereres, D.W. Henderson, and R.M. Hagan. 1984. Evapotranspiration Losses of Tomatoes under Drip and Furrow Irrigation. Calif. Agr. 38(5-6):10-11.

Richards, L.A. and O.R. Neal. 1936. Some field observations with tensiometers. Soil Sci. Soc. Amer. Proc. 1:71-91.

Ryan W. and W. Pitman. 1998. Noah's Flood. The new scientific discoveries about the event that changed history. Simon \& Schuster UK Ltd., London.

Savage, Z. 1953. Does irrigation pay on your grove? AE Ser. no. 54-8. Univ. Fla., Gainesville.

Seckler, D. 1996. The new era of water resources management: From 'dry' to 'wet' water savings. Res. Rpt. 1. Intl. Irr. Mgt. Inst., Colombo, Sri Lanka.

Shackel, K.A., H. Ahmadi, W. Biasi, R. Buchner, D. Goldhamer, S. Gurusinghe, J. Hasey, D. Kester, B. Krueger, B. Lampinen, G. McGourty, W. Micke, E. Mitcham, B. Olson, K. Pelletrau, H. Philips, D. Ramos, L. Schwank1, S Sibbett, R. Snyder, S. Southwick, M. Stevenson, M. Thorpe, S. Weinbaum, and J. Yeager. 1997. Plant water status as an index of irrigation need in deciduous fruit trees. HortTechnology 7:23-29.

Smajstrla, A.G., W.G. Boggess, B.J. Boman, G.A. Clark, D.Z. Haman, G.W. Knox, S.J. Locascio, T.A. Obreza, L.R. Parsons, F.M. Rhoads, T. Yeager, and F.S. Zazueta. 1995. Status and growth of microirrigation in Florida. Proc. 5th Intl. Microirr. Congr., ASAE, Orlando, Fla.

Stoll, M., B.R. Loveys, and P.R. Dry. 2000. Hormonal changes induced by partial rootzone drying of irrigated grapevine. J. Exp. Bot. 51:1627-1634.

Uriu, K. and J.R. Magness. 1967. Deciduous Tree Fruit and Nuts, p. 686-703. In: R.M. Hagan et al. (eds.). Agron. Monog. 11, Irrigation of Agricultural Lands. ASA, Madison, Wis.

van Schilfgaarde, J., L. Bernstein, J.D. Rhoades, and S.L. Rawlins. 1974. Irrigation management for salt control. J. Irr. Drain. Div. Amer. Soc. Civil Eng. 100:321-338.

Veihmeyer, F.J. 1927. Some factors affecting the irrigation requirements of deciduous orchards. Hilgardia 2:125-284.

Veihmeyer, F.J. 1972. The availability of soil moisture to plants: Results of empirical experiments with fruit trees. Soil Sci. 144:268-294.

Villalobos, F.J., F. Orgaz, L. Testi, and E. Fereres. 2000. Measurement and modeling of evapotranspiration of olive (Olea europaea L.) orchards. Euro. J. Agron. 13:155-163.

Walter, I.A., R.G. Allen, R. Elliott, B. Mecham, M.E. Jensen, D. Itenfisu, T.A. Howell, R. Snyder, P. Brown, S. Echings, T. Spofford, M. Hattendorf, R. H. Cuenca, J.L. Wright, and D. Martin. 2000. ASCE's standardized reference evapotranspiration equation. Proc. 4th Natl. Irr. Symp. ASAE, St. Joseph, Mich. 